\title{
TAFSIR DAN IJTIHAD POLITIK PESANTREN: Suatu Perspektif dari Pondok Buntet Pesantren Cirebon
}

\author{
A. Syatori \\ IAIN Syekh Nurjati Cirebon
}

\begin{abstract}
Abstrak: Keterlibatan pesantren dan kyai dalam hal politik selalu menarik untuk diperbincangkan dan menimbulkan pro dan kontra. Apalagi perbincangan itu muncul dari masyarakat sekitar pesantren sendiri, baik penduduk sekitar pesantren, alumni pesantren maupun walisantri. Penelitian ini bertujuan untuk memaparkan tafsir dan ijtihad politik pesantren dengan mengambil lokasi di pesantren Buntet yang merupakan salah satu pesantren tertua di Jawa. Penelitian ini menggunakan metode kualitatif dengan cara pengambilan data wawancara terhadap sumber yang terkait. Hasil dari penelitian ini menunjukan bahwa Pondok pesantren sebagai lembaga dakwah yang berhubungan secara langsung dengan masyarakat sangat menarik perhatian para politisi sebagai bidikan untuk mengangkat suara partai politiknya. Atas dasar itu pula, maka kemudian muncul pandangan masyarakat yang pro dan kontra mengenai keterlibatan pesantren dan kyai dalam persoalan politik praktis.
\end{abstract}

Kata Kunci: Ijtihad Politik, Pesantren Buntet, Kyai

\section{A. Pendahuluan}

Perdebatan tentang keterlibatan pesantren atau mungkin godaan politik praktis terhadap pesantren bukanlah fenomena khas Buntet Pesantren. Hal ini menggejala di hampir seluruh pesantren. Ketika seorang tokoh pesantren menjadi dan atau berambisi menjadi pimpinan di negeri ini maka ia akan menggunakan segala daya dan potensi yang dimiliknya untuk mendukung dirinya, secara kebetulan atau barangkali karena latar belakangnya dari pesantren maka ya ia menggunakan jaringan pesantren untuk mendukung dirinya. Satu pilihan yang wajar.

Keterlibatan pesantren dan kyai dalam hal politik selalu menarik untuk diperbincangkan dan menimbulkan pro dan kontra. 
Apalagi perbincangan itu muncul dari masyarakat sekitar pesantren sendiri, entah itu penduduk sekitar pesantren, alumni pesantren maupun walisantri. Pandangan masyarakat tentang pesantren menjadi penting karena sejak kemunculannya, keberadaan pesantren tidak bisa dilepaskan dari realitas dan dinamika masyarakat. Masyarakat sekitar pesantren menjadi bagian penting dari sejarah perkembangan pesantren. Bahkan dalam pendiriannya, tidak sedikit pesantren dibangun dan disokong oleh masyarakat.

Kontroversi pandangan masyarakat atas keterlibatan pesantren dan kyai dalam persoalan politik (baca: politik praktis) mengemuka menjadi dua arus besar pandangan dengan basis argumentatif yang mendasarinya. Bagi mereka yang menolak, mendasarkan argumentasinya bahwa politik bukanlah dunianya kyai, sebagai pemegang otoritas pesantren. Politik itu dunia yang kotor penuh dengan intrik, manipulasi, kolusi dan konflik. Dalam dunia politik, sangat sulit untuk membedakan siapa dalang dan siapa yang menjadi wayang. Karena bisa saja seseorang tampil sebagai wayang, namun dilain waktu, bisa juga muncul sebagai dalang, alias profokator. Hal ini tentu saja bertolak belakang dengan citra kyai dan pesantren yang sakral. Sudah semestinya politik dipisahkan jauh-jauh dari pesantren. Selain itu, sebagaimana telah dimaklumi bahwa politik di Indonesia sangat sarat dengan fragmentasi kepentingan sesaat, sedangkan kyai merupakan sosok yang membawa misi ketuhanan yang berlaku dalam jangka waktu yang tak terbatas. Jadi, moralitas dan misi keagamaan sangatlah berbeda dengan moralitas dan misi politik. Moralitas dan misi agama bersandar pada citra ilahi yang mengandaikan totalitas pengabdian dan keikhlasan yang terkait dengan dimensi esoterik yang bersifat metafisik sedangkan politik bercorak profan, sekuler dan terkait dengan posisi kuasa. Dengan keterlibatannya dalam politik, citra kyai sebagai da'i dan dakwahnya akan menjadi 'tidak berbobot'.

Sementara itu, bagi yang berpendapat sebaliknya, berpandangan bahwa keterlibatan kyai dan pesantren dalam persoalan politik merupakan suatu keharusan dan kewajaran. Dalihnya, justru karena politik sedang kotor, kehadirannya diharapkan mampu menyemarakkan wacana politik baru kontemporer dan meniupkan arah baru pemikiran politik. Hak politik itu hak asasi manusia. Berpolitik itu bagian dari hak asasi manusia, termasuk kyai. Tidak ada Undang- 
Undang yang melarang kyai berpolitik. Sebagai sosok yang selama ini dianggap penuh dengan kekuatan aura kharismatik serta menempati posisi tinggi (high class) dalam strata sosial, utamanya bagi umat islam, tidak mengherankan jika segala apa yang diucapkan seorang kyai, diyakini sami'nâ wâatho'na. Karena itu, ditengah kian merosotnya citra politik tersebut, kyai harus masuk dan ikut berpartisipasi dalam politik parktis untuk segera memperbaiki semua kebobrokan yang terjadi didalamnya. Terlebih dengan kian merosotnya citra para elite politik dimata masyarakat, hal itu bertolak dari fakta yang terjadi selama ini, perilaku para wakil rakyat kian jauh dari implemantasi amar ma'ruf nahi mungkar. Kalau seorang kyai "lepas tangan", sama halnya ia telah membiarkan kemungkaran semakin merajalela. Sedangkan membiarkan kemungkaran di depan mata, sama juga dengan merestuinya.

Keterlibatan beberapa kyai dalam parade politik merupakan fase yang akan dijadikan momentum untuk melakukan perubahan dan artikulasi sosial kyai terhadap kehidupan sosial-politik yang sedang berkembang. Kondisi kehidupan bernegara yang tidak stabil dan moral politik yang korup dalam menjalankan fungsi kenegaraan, secara moral fakta ini mendorong kyai untuk ikut terlibat dalam kancah perpolitikan nasional, kehadiran kyai dalam dunia politik praktis diharapkan dapat memperabaiki kondisi negara yang sudah tidak menentu. Landasan teologis dan bangunan sejarah negeri ini menjadi dasar pijakan kuat para kyai untuk masuk ke dalam dunia politik. Arah perkembangan dan sistem politik yang tidak lagi mengedepankan nilai-nilai dan akhlaqul karimah memberikan alasan bagi keterlibatan kyai. Seharusnya kyai bersama masyarakat 'ndandani' politik yang sudah terlanjur buruk citranya serta kyai dapat memperbaiki sistem dan kultur politik. Keterlibatan kyai di dunia politik adalah bagian dari fardlu kifayah. Artinya, seluruh umat Islam ikut menanggung dosa jika tak ada satu pun umatnya yang peduli dengan politik, karena politik adalah bagian dari dinamika kehidupan yang tidak bisa ditolak kehadirannya. Sama halnya, jika seluruh umat Islam terjun di dunia politik, sehingga melupakan tugas dakwah, pendidikan, ekonomi, sosial dan keagamaan, maka seluruh umat Islam ikut terbebani dosa. Fardlu kifayah adalah kewajiban keterwakilan, jika sudah ada yang mewakili maka gugurlah kewajiban itu. 
Politik kyai bukan berorientasi pada kekuasaan an sich tapi politik moral. Keterlibatan kyai dalam politik bukan berarti terjun dan turut terlibat langsung dukung-mendukung capres dan cawapres. Kyai tetap boleh berpolitik, tetapi tidak diorientasikan pada kekuasaan, melainkan menanamkan nilai-nilai moral untuk pencerdasan dan penguatan umat dan masyarakat. Jadi, saat kyai berpolitik memang akan muncul permasalahan. Namun masalahnya lebih terletak pada penggunaan otoritas dan penggunaan legitimasi, bukan pada substansi keterlibatan kyai dalam politik praktis. Jadi masalahnya, apakah terjadi 'authority abuse' saat kyai berpolitik atau tidak. Selama tidak ada penyalahgunaan otoritas, maka politik kyai tidak menjadi masalah, bahkan sangat dibutuhkan. Sebenarnya jika kyai bisa bermain politik dengan cantik dan benar itu luar biasa, karena dia mempunyai dasardasar hukum keagamaan.

Dalam ajaran Islam, ulama atau kyai mempunyai kedudukan yang sangat tinggi dan peran yang maha penting dalam kehidupan umat, agama, dan bangsa. Secara garis besar, peran itu berupa tugas pencerahan bagi umat manusia sesuai dengan kedudukannya sebagai para pewaris Nabi (waratsatul anbiya'). Peran itu biasa disebut dengan 'amar ma'ruf nahi munkar. Dalam konteks kehidupan sosial, melakukan 'amar ma'ruf nahi mungkar itu dipahami bukan dalam konteks perintah untuk melakukan ibadah secara personal tetapi perintah untuk melakukan ibadah sosial. Dalam implementasi dan operasionalisasinya, konsep 'amar ma'ruf nahi mungkar itu merujuk pada hadits Nabi yang menerangkan bahwa jika seseorang melihat kemungkaran, maka ia harus mencegahnya dengan tindakan/kekuasaannya. Jika tidak bisa, maka dengan ucapannya dan jika tidak bisa juga, maka dengan hatinya. Jika dikaji menurut ilmu kepesantrenan atau Ushul Fiqh amar makruf nahi mungkar kata amar (perintah) itu bisa dikatakan amar jika posisi orang yang memerintah itu lebih tinggi dari orang yang diperintah, tetapi kalau sebaliknya maka namanya $a d-d u$ 'a, kalau sama posisinya dinamakan iltimas atau himbauan.

Kekuatan agama dan politik itu kembar dua. Kekuatan agama itu pondasi dan politik itu penjagaan. Pesantren adalah kekuatan agama. Ketika pesantren tidak memiliki kekuatan penjaga atau tidak berafiliasi dengan dunia politik, maka pesantren akan rapuh. Terkait 
peran politik pesantren, politik sudah semestinya dimaknai secara luas. Paling tidak terdapat tiga makna politik, pertama: politik kebangsaan, kedua: politik kerakyatan, dan ketiga: politik kekuasaan. Pesantren sudah dapat dianggap memerankan fungsi politiknya ketika ia telah berhasil memberikan pendidikan atau pengabdian sebatas politik kerakyatan dan kebangsaan, seperti memberdayakan ekonomi masyarakat, memberikan pembinaan wawasan kebangsaan dan pembelaan hak-hak kebangsaan masyarakat (umat), melakukan diplomasi pendidikan, menjalin kerjasama dunia pensatren secara internasional, dan lain-lain.

\section{B. Pembahasan}

\section{Pondok Buntet Pesantren dalam Lintasan Sejarah}

Pondok Pesantren Buntet berada di blok Manis Depok Pesantren, bagian utara desa Mertapadakulon Kecamatan Astanajapura Kabupaten Cirebon. Letak desa Mertapadakulon adalah $12 \mathrm{~km}$ ke arah selatan dari Kota Cirebon, $26 \mathrm{~km}$ ke arah timur dari ibu kota Kabupaten Cirebon. Perjalanan menuju desa seluas 127,43 hektar ini dapat ditempuh dengan bus atau minibus jurusan Cirebon-Ciledug lewat Sindanglaut. Kedudukan Pesantren Buntet berada di antara empat perbatasan yaitu sebelah barat, berbatasan dengan desa Munjul, sebelah utara berbatasan dengan sungai Cimanis desa Buntet, sebelah timur berbatasan dengan Kali Anyar, dan sebelah selatan berbatasan dengan blok Kiliyem desa Sida Mulya. Kompleks pesantren terletak 700 m dari jalan utama Cirebon-Ciledug dari arah kantor desa dan dihubungkan dengan jalan utama oleh jalan desa.

Data tertulis mengungkapkan, Pondok Pesantren Buntet didirikan pada tahun 1750 oleh Kyai Muqayim bin Abdul Hadi, yang dikenal dengan nama Mbah Muqayim, seorang Penghulu Kraton atau Mufti Kraton Kanoman. Mbah Muqayim, yang menentang campur tangan Belanda dalam urusan kraton dan menyaksikan betapa sebagian bangsawan kraton telah terjebak dalam aturan Belanda -banyak diantara mereka malah berperilaku bertentangan dengan syari'ah, seperti berdansa-dansi dan minum alkohol- meninggalkan kraton dan memutuskan tinggal di luar lingkungan kraton (Muhaimin: 311). Sepeninggal dari kraton dan 
mengambil sikap anti-kolonial, oposisi dan non-kooperatif dengan Belanda, mbah Muqayim menjadi seorang pejuang dan gerilyawan yang selama hidupnya selalu dikejar-kejar tentara Belanda. Ia selalu berpindah-pindah dari satu daerah ke daerah lain dalam upaya mencari perlindungan hingga ia menemukan "daerah aman" dari kejaran tentara Belanda. Sehingga ia menemukan sebuah daerah, di blok Kedungmalang, sebuah dusun di Buntet (Muhaimin: 312). Di situ, ia lalu mendirikan sebuah bangunan untuk "tempat berlindung" dari kejaran tentara Belanda. Bangunan yang yang berukuran $8 \times 12 \mathrm{M}$ itulah di kemudian hari dikenal dengan sebutan "Buntet" yang berarti tempat perlindungan. Di dalam "Buntet" itu, mbah Muqayim membuat mushalla yang berfungsi sebagai tempat shalat dan pendidikan keagamaan (pesantren). Namun, tidak lama kemudian tempat persembunyian itu ditemukan lagi oleh tentara Belanda. Ki Ardisela, seorang kepala dusun Dawuan yang mengetahui manuver Belanda tersebut segera mengabarkan Mbah Muqayyim, sehingga keluarga dan seluruh santrinya berhasil pindah dengan selamat ke Pesawahan sebelum Belanda tiba dan mengepung pesantren. Untuk sementara kegiatan pesantren terhenti dan Mbah Muqayim berkelana dari satu tempat ke tempat lain guna menghindari penangkapan Belanda. Tempat-tempat persinggahan selama masa pelariannya antara lain dusun Pesawahan di desa Lemahabang, Tuk di Karangsuwung, dan Beji di Pemalang (Jawa Tengah). Setelah melewati petualangan panjang, ia kembali ke Buntet pada tahun 1758 dan mendirikan pesantren baru di blok Gajah Ngambung. Salah seorang santri pertamanya adalah Pangeran Khaeruddin, putera Sultan Kanoman (Khaeruddin I). Ketika Sultan wafat pada tahun 1798, Belanda menobatkan Tumenggung Surantaka dan membuang Pangeran Khaeruddin, sang pewaris tahta sejati, ke daerah pengasingan di Ambon. Mbah Muqayim menentang penobatan ini dan menggerakkan pemberontakan rakyat untuk memaksa Belanda agar mengembalikan Pangeran Khaeruddin ke Cirebon (Muhaimin: 313).

Sepeninggal mbah Muqayim, Pondok Buntet Pesantren dipimpin oleh kyai Muta'ad. Ia dilahirkan pada tahun 1785 M., putra Raden Muridin bin Raden Muhammad Nurudin (keturunan 
ke-17 dari Syarif Hidayatullah). Ia merupakan salah seorang santri yang terpandai dari mertuanya yaitu Raden Muhammad (anak tunggal mbah Muqayim). Dalam membina dan memimpin Pondok Pesantren Buntet, Kyai Muta'ad selalu bercermin kepada kepemimpinan mbah Muqayyim yang tidak pernah kompromi dengan Belanda. Meski keturunan Keraton Cirebon, ia berjiwa patriot dan anti-kolonial. Boleh dikata, ia juga merupakan salah seorang pejuang dan anti feodalisme, sebaliknya ia lebih memperhatikan nasib masyarakat banyak. Pernyataan tersebut ia buktikan dengan tidak menggunakan nama kebangsawanannya sikap ini, ia wariskan kepada anak cucunya- sebagai protes atas perilaku kakek neneknya yang bekerja sama dengan Belanda. Sebaliknya, ia justeru malah menyebarkan anak cucunya untuk mendirikan pondok pesantren di berbagai daerah antara lain di Gedongan (Pondok Pesantren Gedongan, melalui keturunan dari Ny. Maemunah) dan di Benda Kerep Kota Cirebon (Pondok Pesantren Benda melalui keturunan dari KH. Tarmidzi).

Penerus kyai Muta'ad adalah anak keempatnya, kyai Abdul Jamil. Ia menggantikan kakak-kakaknya yang tidak dapat meneruskan kepemimpinan kyai Muta'ad karena pernikahan dengan wanita di luar pesantren. Selama memimpin, kyai Abdul Jamil bekerja keras memajukan pesantren baik dalam bidang pengelolaan maupun aspek akademis. Di bawah kepemimpinannya jumlah santri pernah mencapai 700 orang, datang dari berbagai wilayah Jawa, Sumatera, Sulawesi dan Singapura. Untuk mengakomodasi jumlah santri yang terus bertambah, gedunggedung baru didirikan dan juga sebuah masjid besar (masjid jami') yang biayanya ditanggung oleh para donatur, khususnya para lulusan pesantren yang telah sukses (Muhaimin: 318). Kyai Abdul Jamil memprakarsai dislenggarakannya pengajian kitab kuning elementari dan tadarrus al-Quran pada setiap bulan ramadlan. Pengajian kitab kuning elementari yang dilaksanakan pada bulan ramadlan ini kemudian dikenal dengan sebutan ngaji pasaran, waktunya setelah shalat dzuhur dan shalat ashar; sedangkan tadarrus al-quran dilaksanakan ba'da shalat taraweh dan menjelang shalat shubuh, dengan diisi bacaan-bacaan ayat al- 
Quran oleh para santri dan qori kenamaan seperti kyai Shaleh Ma'mun (Banten), kyai Mansur Ma'mun dan kyai Syihabuddin.

Pembangunan mental dan spiritual dilaksanakan serentak dengan pembangunan fisik, oleh karenanya di samping membangun asrama atau pondok, masjid jami', tempat-tempat pengajian umum thariqah sebagai suatu usaha mencari ketengangan dan ketenteraman jiwa dalam beribadah juga tumbuh dan berkembang dengan pesat. Thariqah mu'tabaroh yang tumbuh dan menjadi pegangan beliau khususnya dan para pembina Pesanten Buntet umumnya adalah thariqah syatariyah dengan jumlah pengikut yang cukup banyak hampir di seluruh pelosok tanah air.

Setelah kyai Abdul Jamil, kepemimpinan Buntet Pesantren ditampuk oleh kyai Abbas. Ia adalah putra pertama kyai Abdul Jamil dari pernikahannya dengan nyai Qoriah, dilahirkan pada 24 Dzulhijjah 1300 H./1879 M di Pekalangan Cirebon. Kyai Abbas belajar ilmu-ilmu keagamaan pertama sekali memperoleh bimbingan dari orang tuanya kyai Abdul Jamil. Kemudian oleh orang tuanya dikirim ke kyai Nasukha di Sukunsari (Plered), selanjutnya beliau belajar kepada kyai Hasan (Jatisari, Majalengka), kepada kyai Ubaedah (Tegal), kepada KH. Hasyim Asyari (Tebuireng, Jombang), kepada KH. Wahab Hasbullah (Jawa Tengah), dan bersama KH. Abdul Manaf Lirboyo Kediri turut membuka Pondok Pesantren Lirboyo Kediri Jawa Timur. Setelah dianggap dewasa, kyai Abbas dikirim orang tuanya ke Makkah untuk menunaikan ibadah haji, tetapi selama di Makkah beliau belajar kepada KH. Makhfudz Termas bersama KH. Bakir (Yogyakarta) dan KH. Abdillah (Surabaya). Saat itu, bahkan ia telah memberikan pelajaran kepada para mukimin di Mekah dalam bidang ilmu fiqh. Diantara santrinya ialah KH. Kholil (Balerante, Palimanan), KH. Sulaiman (Babakan, Ciwaringin). Setelah kembali dari Makkah, ia diserahi Pondok pesantren Buntet. Dengan bermodal ilmu pengetahuan yang diperoleh dari berbagai pesantren di Jawa, kemudian dipermatang lagi dengan keilmuan yang dipelajari dari Mekah, serta upayanya mengikuti perkembangan pemikiran Islam yang terjadi di Timur Tengah pada umumnya, maka mulailah Kiai Abbas memegang tampuk 
pimpinan Pesantren Buntet Waruisan dari nenek moyangnya itu dengan penuh kesungguhan.

Sifat dan kepribadian sang ayah, kyai Abdul jamil, diwarisi dan dimiliki kyai Abbas. Pada masanya, organisasi dan administrasi pesantren Buntet disempurnakan dan pembagian tugas serta wewenang dipertegas dan penempatan tenaga sesuai dengan keahliannya, pengiriman kader diperbanyak, tukar menukar tenaga guru dan santri pesantren lain dilaksanakan, di tempatkannya tenaga sukarela di daerah-daerah. Intensifikasi kepemimpinan dengan kepribadian yang luwes dapat mengangkat martabat Pesantren Buntet serta meletakkannya pada proforsi yang tepat di tengah-tengah tarikan dan gerakan-gerakan empat jaman yang paradoksal yaitu jaman penjajahan Belanda I, penjajahan Jepang, penjajahan Belanda II dan jaman kemerdekaan. Pada tahapan penerus ini sistem pendidikan semakin ditingkatkan, begitu juga dengan teknik maupun metode. Sistem khas kepesantrenan, dilengkapi dengan sistem madrasah dengan maksud agar saling mengisi dan melengkapi di antara kedua sistem tersebut. Sistem pesantren yang memberikan keluasan kepada santri dalam menyelami kitab kuning lebih tinggi dan lebih luas, di samping itu sistem madrasah membuat santri akan mampu berfikir praktis, sistematis dan terarah dalam mewujudkan pola berfikir ilmiah pragmatis, orisinil dengan adanya integrasi dan toleransi antara kedua sistem tersebut. Salah satu terobosan utama yang dilakukan Kyai Abbas adalah pengenalan sistem madrasah di pesantren sembari tetap mempertahankan sistem pengajaran tradisional seperti sorogan, bandungan, dan ngaji pasaran. Pada 1928 beliau mendirikan Madrasah Abnaul Wathan Ibtidaiyah yang mengajarkan bidang studi umum (Muhaimin: 322). Dalam hal ini Kyai Abbas mengambil pedoman dari perkataan Imam Syafi'i: "Peliharalah nilai lama yang baik dan ambil nilai baru yang lebih baik," yang kemudian menjadi motto Pesantren Buntet. Nama Madrasah Abnaul Wathan", yang secara harfiah berarti sekolah untuk anak rakyat, jelas berbau patriotis dan dipilih karena sesuai dengan semangat nasionalis.

Kyai Abbas mengalami berbagai fase kekacauan politik: kolonialisme Belanda pra-PD II, fasisme Jepang, agresi militer 
Belanda dan perjuangan kemerdekaan Indonesia. Selama masamasa bersejarah ini ancaman dan agresi militer baik dari Jepang maupun Belanda menjadi kendala utama bagi perkembangan pesantren. Buntet sendiri beberapa kali menjadi sasaran serangan militer Belanda, yang mengakibatkan kerusakan besar dan penderitaan orang banyak. Sebagaimana orangtua dan kakeknya yang pejuang, kyai Abbas hidup di empat zaman, beliau juga besama adiknya kyai Anas turut berjuang memanggul senjata dalam mempertahankan kedaulatan negara RI. Bersama adiknya, ia memanggul senjata bersama para pejuang lainnya di tengah-tengah kancah peperangan pada 10 Nopember di Surabaya. Di samping itu, sebagai pemimpin Pesantren, ia mengirimkan beberapa orang santrinya ke Jakarta, Cianjur, Bekasi dan daerah-daerah lain dalam turut serta melawan penjajah sesudah penandatanganan persetujuan Linggarjati.

Pada masa kepemimpinan kyai Abbas, Pesantren Buntet dijadikan markas pergerakan kaum Republik, untuk melawan penjajahan. Mulai saat itu, pesantren Buntet menjadi basis perjuangan umat Islam melawan penjajah yang tergabung dalam barisan Hisbullah. Organisasi ini di ketuai langsung oleh kyai Abbas dan adiknya, kyai Anas, serta dibantu ulama lain, seperti kyai Murtadlo, kyai Sholeh, dan kyai Mujahid. Karena itu muncul tokoh Hisbullah di zaman pergerakan Nasional yang berasal dari Cirebon, seperti KH Hasyim Anwar, dan KH Abdullah Abbas, putra Kiai Abbas. Ketika melakukan perang grilya, tentara Hisbullah memusatkan perhatiannya di daerah Legok, Kecamatan Cidahu, Kabupaten Kuningan, dengan front di perbukitan Cimaneungteung, yang terletak di daerah Walet selatan membentang ke bukit Cihirup, Kecamatan Ciipancur, Kuningan. Daerah tersebut terus dipertahankan sampai terjadinya perundingan Renville tahun 1947, ketika kemudian pemerintah RI beserta semua tentaranya hijrah ke Yogjakarta pada tahun yang sama. Basis-basis kekuatan laskar yang dibangun oleh Kyai Abbas itu kemudian menjadi pilar penting bagi tercetusnya Revolusi November di Surabaya tahun 1945. Peristiwa itu terbukti setelah KH Hasyim Asy'ari mengeluarkan Resolusi Jihad pada 22 Oktober 1945, Bung Tomo segera datang berkonsultasi kepada KH. Hasyim 
Asy'ari guna minta restu dimulainya perlawanan terhadap tentara Inggris. Tetapi KH Hasyim menyarankan agar perlawanan rakyat itu tidak dimulai terlebih dahulu sebelum Kyai Abbas dan laskar andalannya datang ke Surabaya. Hubungan Kyai Hasyim dengan Kyai Abbas sesungguhnya memang sudah lama terjalin. Terlihat ketika pertama kali Kyai Hasyim mendirikan pesantren Tebuireng, Kyai sakti dari Cirebon ini banyak memberikan perlindungan, terutama saat diganggu oleh para penjahat setempat, yang merasa terusik oleh kehadiran pesantren Tebuireng. Sekitar tahun 1900, kyai Abbas datang dari Buntet bersama kakak kandungnya, kyai Soleh Zamzam, Benda Kerep, kyai Abdullah Penguragan dan Kyai Syamsuri Wanantara. Berkat kehadiran mereka itu para penjahat yang dibeking oleh Belanda, penguasa pabrik gula Cukir itu tidak lagi mengganggu pesantren Tebuireng, tidak berani mengganggu lagi. Selain mendirikan Hisbullah, pada saat itu di Buntet Pesantren juga dikenal adanya organisasi yang bernama Asybal. Inilah organisasi anak-anak yang berusia di bwah 17 tahun. Organisasi ini sengaja dibentuk oleh para sesepuh Buntet Pesantren sebagai pasukan pengintai atau mata-mata guna mengetahui gerakan musuh sekaligus juga sebagai penghubung dari daerah pertahanan sampai ke daerah front terdepan. Hingga akhir hayatnya, kyai Abbas akif baik dalam pergerakan sosial keagamaan maupun politik. Keikutsertaannya dalam berbagai kegiatan dan jaringan dapat dirunut sebagai berikut: 1) pemimpin pesantren, 2) Mursyid tarekat Syattariyah, 3) Muqaddam tarekat Tijaniyah, 4) penasehat religius SDI, 5) Anggota Dewan Pusat Muhtasyar NU, 6) Rais 'Am Dewan Syuriah NU Jawa Barat, 7) Anggota Sangikai dan Sangi-in pada masa pendudukan Jepang, 8) Komandan Sabilillah dan Hizbullah, 9) Wakil ulama Jawa Barat dalam KNIP. (Muhaimin, 2002: 326).

Pasca kyai Abbas, Buntet Pesantren dipimpin oleh putera tertuanya, kyai Mustahdi Abbas. Ia belajar agama pada ayahnya Kyai Abbas dan paman-pamannya, kyai Anas, kyai Ilyas dan kayi Akyas. Ia kemudian belajar ke Pesantren babakan Ciwaringin pada kyai Amin, ke Termas pada kyai Dimyati, ke Tebuireng pada kyai Hasyim Asy'ari, ke Lirboyo pada kyai Abdul Karim dan ke Lasem apad kyai Ma'mun dan kyai Baidlowi. Dalam hal 
kepemimpinannya di pesantren, kyai Mustahdi memberi perhatian khusus pada pengembangan sistem madrasah. Salah satu kerja kerasnya adalah upaya membuat Buntet Pesantren menjadi bagian integral dari sistem pendidikan nasional. Pada tahun 1950 ia mengembangkan madrasah tiga tahun yang didirikan oleh ayahnya menjadi Madrasah Ibtidaiyah dengan lama belajar enam tahun. Dipengaruhi faktor ke-NU-annya yang kental, pada tahun 1958 ia mendirikan PGA 4 tahun NU sebagai tambahan bagi pendidikan menengah di pesantren. Pada tahun 1960, sekolah ini dikembangkan menjadi dua lembaga pendidikan terpisah, yaitu PGA 6 tahun NU Putera dan PGA 6 tahun NU Puteri. Pada tahun 1965 ia juga mendirikan Madrasah Tsanawiyah NU, dan pada tahun 1968 madrasah Aliyah NU. Terakhir pada tahun 1970, ia mendirikan Uniersitas Islam Cakrabuana dengan dua fakultas, Tarbiyah dan Ushuluddin. Belakangan kedua fakultas ini diafiliasikan dengan IAIN Sunan Gunung Jati Bandung (Muhaimin, 2002: 328). Kyai Mustahdi juga menaruh perhatian besar dalam mengembangkan manajemen pesantren dan meletakkan dasar struktur organisasi dinama semua madrasah yang berada di lingkungan pesantren diintegrasikan ke dalamnya. Lembaga Pendidikan Islam (LPI) yang ada sekarang didirikan sebagai penghormatan kepada kyai Mustahdi. Lembaga ini dibentuk tanggal 17 Agustus 1958. Pada tahun 1967, kyai Mustahdi mengimbau seluruh alumni Buntet untuk mengadakan kongres membahas isu-isu kontemporer, khususnya yang berkaitan dengan dunia pendidikan Islam. Dalam kongres ini berbagai isu bermunculan dan terbentuk suatu organisasi yang disebut IKPB (Ikatan Keluarga Buntet Pesantren) (Muhaimin, 2002: 329).

Sepeninggal kyai Mustahdi, puteranya, Abbas Shobih, masih kecil, sehingga adik kandungnya, kyai Mustamid Abbas ditunjuk sebagai pengganti. Kyai Mustamid telah berusia 60 tahun ketika mengambil alih pimpinan pesantren dan sudah cukup disibukkan dengan urusan lain. Ia adalah Rais Syuriah PBNU Jawa Barat, anggota MPR, Ketua Persatuan Pondok Pesantren Indonesia cabang Cirebon. Pendidikannya dimulai di Madrasah Wathoniyah Buntet Pesantren. Stelah itu ia melanjutkan ke Termas, Lasem, Lirboyo dan Kulliyatul Muballighin di Tebuireng Jombang. Ia 
tidak menetapkan hal-hal baru dalam memimpin pesantren, tetapi melanjutkan kebijakan yang telah dirintis oleh kakaknya. Dalam pada itu, Departemen Agama RI tengah menjalankan reorganisasi sistem pendidikan agama. Reorganisasi ini berdampak besar pada struktur organisasi pendidikan agama di Indonesia secara keseluruhan, khususnya mengenai penyelenggaraan PGA dan IAIN. Dalam skema yang baru, PGA ditransformasikan menjadi Madrasah Aliyah biasa, dan sejak itu pendidikan madrasah yang diselenggarakan di Buntet menjadi: (1) Madrasah Wathoniyah Ibtidaiyah Puteri (2) Madrasah Wathoniyah Ibtidaiyah Putera (3) Madrasah Tsanawiyah NU Putera I (4) Madrasah Tsanawiyah NU Putera II (5) Madrasah Tsanawiyah NU Puteri (6) Madrasah Aliyah NU Putera-Puteri (7) Madrasah Aliyah NU Puteri dan (8) Madrasah Aliyah Negeri.

Ketika kyai Mustamid meninggal tahun 1988, Abbas Shobih, putera kyai Mustahdi yang sebenarnya berhak melanjutkan kepemimpinan pesantren, belum beranjak dewasa dan belum siap untuk bertindak sebagai sesepuh pesantren. Suatu konsensus diantara shohibul wilayah akhirnya tercapai ketika menyelenggarakan peringatan 7 hari wafatnya kyai Mustamid dan menunjuk kyai Abdullah Abbas, putera kyai Abbas, yang akrab dipanggil Ki Dulah, menjadi sesepuh. Kyai Abdullah Abbas lahir di Buntet Pesantren pada tanggal 7 Maret 1922. Sejak kecil, Ki Dulah mendapat pembinaan yang serius oleh ayahnya, Kyai Abbas. Maka tak ayal bila jejak-jejak dan pola hidup Kyai Abbas banyak ditiru olehnya. Selain itu, ia mendapat gemblengan dari beberapa Pesantren. Pesantren yang pertama kali disinggahi adalah pesantren di Pemalang yang dipimpin oleh Kyai Makmur. Selepas dari Pemalang Jawa Tengah, Kyai Abdullah Abbas menimba ilmu pada Kyai Ma'sum di Lasem Jawa Tengah. Rampung dari Lasem, Ki Dulah berguru pada Hadratus Syekh KH. Hasyim Asy'ari Jombang Jawa Timur, dan terakhir digembleng oleh Kyai Abdul Karim Manaf di Lirboyo. Selepas dari Pondok Pesantren, kyai Abdullah Abbas langsung berkiprah di masyarakat. Dengan diserahi sebagai Ketua Batalyon Hisbullah, ia berjuang merebut kemerdekaan. Selepas revolusi fisik, ia mengalihkan perjuanganya dari mengangkat senjata beralih pada berdakwah 
langsung di masyarakat. Jabatan kemiliterannya (Letnan Muda) ditinggalkan dan lebih memilih menjadi Juru Warta pada Juru Penerangan Agama Kabupaten Cirebon. Lalu menjadi Pengatur Guru Agama Islam Kabupaten Cirebon dan Jabatan terakhir adalah Kepala MAN Buntet Pesantren Kabupaten Cirebon.

\section{Rahim Politik Pondok Buntet Pesantren}

"Pondok Buntet Pesantren terlahir dari rahim politik". Ungkapan ini barangkali cukup layak disematkan kepada Buntet Pesantren kaitannya dengan perjuangan politik pesantren tersebut. Betapa tidak, sejak pertama dibangun oleh pendirinya, Mbah Muqayyim, pada tahun 1750-an, pesantren ini tidak sebatas sebagai pesantren dalam pengertian padepokan tempat orang menuntut ilmu semata, melainkan sebuah pilihan strategi yang dilakukan oleh Mbah Muqoyyim sebagai bentuk perlawanan tidak saja terhadap kolonialisme Belanda melainkan juga terhadap sikap kraton Cirebon yang takluk di bawah Belanda. Buntet Pesantren pada masanya sebagai poros gerakan perlawanan di Cirebon atas penindasan terhadap rakyat yang dilakukan oleh Belanda, sebagai poros gerakan politik anti-kolonial.

Pilihan politik anti-kolonial dan non-kooperatif terhadap Belanda ini terus terjaga hingga beberapa generasi penerus pesantren ini. Kyai Muta'ad, dalam membina dan memimpin Pondok Pesantren Buntet selalu bercermin kepada kepemimpinan mbah Muqayyim yang tidak pernah kompromi dengan Belanda. Meski keturunan Keraton Cirebon, ia berjiwa patriot dan antikolonial. Boleh dikata, ia juga merupakan salah seorang pejuang dan anti feodalisme, sebaliknya ia lebih memperhatikan nasib masyarakat banyak. Pada masanya, banyak kyai-kyai yang membantu berasal dari mufti di Keraton, seperti Ki Kriyan. Startegi Buntet lebih bersikap akomodatif dengan keraton. Buntet tidak melakukan perlawanan secara langsung terhadap Belanda dan Keraton, melainkan dengan mempengaruhi pola pikir para pembesar kerajaan.

Penerus kyai Muta'ad, kyai Abdul Jamil juga dikenal sebagai tokoh yang konsisten mempertahankan prinsip nonkooperatif dengan Belanda. Pada masanya, strategi perpolitikan 
Buntet berubah. Beliau lebih memilih sikap keras tetapi anggun dalam berdiplomasi. Di kalangan politisi, kyai Abdul jamil sangat akrab dengan mantan siswanya, H. Samanhudi, yang sukses menjadi pedagang batik di Surakarta dan yang pada tahun 1911 mendirikan Sarekat Dagang Islam dalam bentuk koperasi pedagang batik Jawa. Dalam organisasi ini kyai Abdul Jamil aktif di dewan Syuriah hingga wafatnya pada tahun 1919 (Muhaimin: 319)

Sepeninggal kyai Abdul Jamil, Buntet dinahkodai oleh anaknya, kyai Abbas. Sebagaimana orangtua dan kakeknya yang pejuang, kyai Abbas hidup di empat zaman, beliau juga besama adiknya kyai Anas turut berjuang memanggul senjata dalam mempertahankan kedaulatan negara RI. Bersama adiknya, ia memanggul senjata bersama para pejuang lainnya di tengah-tengah kancah peperangan pada 10 Nopember di Surabaya. Di samping itu, sebagai pemimpin Pesantren, ia mengirimkan beberapa orang santrinya ke Jakarta, Cianjur, Bekasi dan daerah-daerah lain dalam turut serta melawan penjajah sesudah penandatanganan persetujuan Linggarjati.

Kyai Abbas mengalami berbagai fase kekacauan politik: kolonialisme Belanda pra-PD II, fasisme Jepang, agresi militer Belanda dan perjuangan kemerdekaan Indonesia. Selama masamasa bersejarah ini ancaman dan agresi militer baik dari Jepang maupun Belanda menjadi kendala utama bagi perkembangan pesantren. Buntet sendiri beberapa kali menjadi sasaran serangan militer Belanda, yang mengakibatkan kerusakan besar dan penderitaan orang banyak.

Pada masa kepemimpinan kyai Abbas, Pesantren Buntet dijadikan markas pergerakan kaum Republik, untuk melawan penjajahan. Mulai saat itu, pesantren Buntet menjadi basis perjuangan umat Islam melawan penjajah yang tergabung dalam barisan Hizbullah. Organisasi ini di ketuai langsung oleh kyai Abbas dan adiknya, kyai Anas, serta dibantu ulama lain, seperti kyai Murtadlo, kyai Sholeh, dan kyai Mujahid. Karena itu muncul tokoh Hisbullah di zaman pergerakan Nasional yang berasal dari Cirebon, seperti KH Hasyim Anwar, dan KH Abdullah Abbas, putra Kiai Abbas. 
Pada masa pendudukan Jepang, kyai Abbas menjadi anggota Kongres Rakyat (Sangikai). Berbekal ilmu latihan militer ketika bergabung dengan tentara PETA, ia terlibat langsung dalam pertempuran dalam agresi militer Belanda pasca PD II dengan membonceng tentara sekutu dan bermaksud mengancam kemerdekaan Indonesia yang diproklamirkan oleh Soekarno-Hatta pada tanggal 17 Agustus 1945. Kyai Abbas sendiri saat itu adalah komandan Sabilillah dan Hizbullah, keduanya adalah sayap Islam dari Korps Pembela Kemerdekaan Indonesia. Ia memimpin pasukan yang terdiri atas sejumlah kyai dan santri terlatih di Surabaya untuk diterjunkan pada pertempuran patriotis melawan sekutu tanggal 10 November 1945. Pasukannya memasuki Jombang pagi Subuh tanggal 9 November 1945. (Muhaimin : 325326)

Selain itu, Kyai Abbas juga ikut memutuskan tanggal 10 November 1945 sebagai hari-H penyerangan terhadap markas tentara sekutu di Surabaya. Hari penyerangan ini diperingati sebagai hari Pahlawan. Kedudukan kyai Abbas di mata kyai Hasyim Asy'ari pada momentum itu dicatat dalam episode berikut : ketika Bung Tomo, yang kemudian mengomandoi tentara RI, tidak sabar mendesak kyai Hasyim Asy'ari agar segera menentukan hari-H penyerangan terhadap markas tentara sekutu di Surabaya, kyai Hasyim menjawab: “...harap bersabar, kami masih menunggu kedatangan para kyai dari Cirebon”.

Sebelum itu, ia juga ikut mendeklarasikan Deklarasi Jihad bersama barisan ulama. Deklarasi ini mengimbau setiap Muslim untuk berperang melawan kafir (Belanda) dan bahwa berperang membela tanah air termasuk perang suci (jihad). Selain mendirikan Hisbullah, pada saat itu di Buntet Pesantren juga dikenal adanya organisasi yang bernama Asybal. Inilah organisasi anak-anak yang berusia di bawah 17 tahun. Organisasi ini sengaja dibentuk oleh para sesepuh Buntet Pesantren sebagai pasukan pengintai atau mata-mata guna mengetahui gerakan musuh sekaligus juga sebagai penghubung dari daerah pertahanan sampai ke daerah front terdepan. 


\section{3. "Bermain" Politik di Tengah Perubahan}

Sejarah panjang pengalaman dan rahim politik yang begitu kuat melekat pada Pondok Buntet Pesantren, berimbas pada kematangan dan kelincahannya dalam merespon segala bentuk perubahan situasi politik multipartai di negeri ini. Politik bagi Buntet Pesantren bukanlah sesuatu yang menakutkan, yang harus dijauhi. Tetapi sesuatu yang "biasa-biasa" saja. "Hal yang tak bisa dilaksanakan orang lain adalah orang lain terlalu mensakralkan politik. Di sini tidak. Hari ini saya PDI besok Golkar gak masalah". ${ }^{1}$ Politik harus bisa dijinakkan dan dimanfaatkan, dan bukan sebaliknya, pondok pesantren dimanfaatkan oleh kepentingan politik para politisi. "Daripada mereka (politisi, red.) memanfaatkan kita, memusingkan kita, lebih baik kita memanfaatkan mereka, memusingkan mereka. Daripada dibingungkan dan dimanfaatkan oleh partai, lebih baik membingungkan dan memanfaatkan partai untuk kemashlahatan umat". 2

Sikap santai dalam berpolitik tersebut sebagai bentuk ijtihad politik yang diambil ketika susana politik mutakhir penuh carut marut dengan kepentingan sekterian partai politik. Bagi Buntet Pesantren, semua partai politik yang ada sama saja, hanya memperjuangkan kepentingan kelompoknya saja. Maka, akan sangat naif jika Buntet Pesantren hanya condong pada salah satu partai politik. Keuntungan dari pilihan sikap politik seperti ini adalah “...sekarang Buntet bukan lagi pesantren politik yang sudah terkapling-kapling, dianggap pesantren yang netral, sesuai dengan khittah. Inilah sikap yang benar, inilah yang diinginkan oleh NU. Pesantren itu harus menjaga jarak yang sama dengan semua partai, semua steak holder politik". ${ }^{3}$

Sikap ini juga berdampak pada sikap terbuka Buntet Pesantren menerima kepentingan politik manapun. Artinya, meski secara kelembagaan Buntet Pesantren tidak berafiliasi dengan

\footnotetext{
${ }^{1}$ Wawancara dengan KH. Muhammad Fariz, Pengasuh Pondok Buntet Pesantren. Ahad, 23 September 2012.

${ }^{2}$ Wawancara dengan KH. Adib Rofiuddin Izza, Pengasuh Pondok Buntet Pesantren. Jum'at, 21 September 2012.

${ }^{3}$ Wawancara dengan Didi Khumaedi, Tokoh Masyarakat, Senin, 26 November 2012.
} 
partai politik manapun, namun masing-masing individu kyai di pesantren ini memiliki independensi pilihan politik sendiri-sendiri. Tidak ada keseragaman pilihan politik mereka terkait dengan partai dan wakil legislatif. Masing-masing memiliki kedekatan dengan parpol, anggota legislatif dan pemerintah secara berbeda-beda. ${ }^{4}$ Demi menjembatani perbedaan ini, Buntet pesantren memiliki cara unik dalam melakukan komunikasi politik terkait pengelolaan pesantren dengan didirikannya Qashrud Duyuf/Guest House (ruang tamu).

Siginifikansi ruang tamu ini bagi strategi politik Buntet Pesantren terletak dari fungsinya sebagai 'penampung' semua 'tamu politik' yang datang berkunjung ke pesantren ini. Kunjungan tertentu dari para tokoh nasional akan disambut di ruang tersebut. Jika tamu itu datang secara personal dan hendak bertamu pada salah satu kyai, maka ia akan 'digiring' ke kediaman kyai tersebut. Jika tamu tersebut tidak menyebutkan secara khusus untuk mendatangi kyai tertentu dari para kyai di Pesantren Buntet, maka tamu tersebut akan diterima bersama di ruang itu. Dialog politik akan dilakukan secara terbuka di tempat itu. Semua dapat berpartisipasi melalui komunikasi di ruang ini. ${ }^{5}$ Yang menarik dari tempat ini adalah siapapun dan kapanpun 'tamu politik' itu datang dipersilahkan. Jadi, pagi hari Anas Urbaningrum berkunjung, lalu siangnya Aburizal Bakri tidak menjadi persoalan. Bahkan jika mereka datang bersamaan pun tidak masalah.

Dengan mencermati kondisi perpolitikan kontemporer yang penuh manipulasi, strategi pilihan politik yang ditempuh Buntet Pesantren ini cukup logis dan rasional. Dalam pandangan kyai-kyai Buntet "tidak ada praktek politik yang beres dan bertanggungjawab baik di partai yang berbasis keagamaan maupun yang tidak. Tidak ada partai yang benar-benar bekerja untuk pentingan rakyat. Mobilisasi uang di partai hampir diwarnai oleh pemanfaatan dana tanpa jelas peruntukannya". ${ }^{6}$ Karenanya, demi menjaga

\footnotetext{
${ }^{4}$ Wawancara dengan KH. Adib Rofiuddin Izza, Pengasuh Pondok Buntet Pesantren. Jum'at, 21 September 2012.

${ }^{5}$ Ibid.

${ }^{6}$ Wawancara dengan KH. Adib Rofiuddin Izza, Pengasuh Pondok Buntet Pesantren. Jum'at, 21 September 2012.
} 
kepentingan pesantren, politik transaksional merupakan pilihan yang logis. Nilai tawar pesantren mesti dinaikkan, dan para kyai Buntet sadar betul bahwa mereka memiliki nilai tawar dengan partai-partai politik yang ingin bekerjasama. Nilai tawar ini digunakan untuk mendapatkan kemashlahatan dari keterlibatan mereka dalam berpolitik praktis, yaitu kemashlahatan bagi penguatan pondok pesantren. Kekuatan-kekuatan yang disadari sebagai nilai tawar itu diantaranya adalah pengaruh kharisma sosial-keagamaan, jaringan alumni di wilayah Cirebon dan Jawa Barat dan pengaruh simbolik keberadaan Cirebon sebagai pusat Islam di Jawa Barat.

Kemaslahatan merupa dalam bentuk keuntungankeuntungan. Dalam hal ini para kyai berbeda-beda dalam memaknai arti keuntungan ini. Diantara mereka ada yang mendeskripsikan keuntungan sebagai hal kongkrit, yaitu sumbangan dana dari partai politik yang ingin didukung oleh pesantren. ${ }^{7}$ Kyai yang lain menyebutkan keuntungan selain bagi pondok pesantren juga bagi organisasi NU secara umum. Partai tertentu atau pemimpin politik tertentu akan dibantu jika nanti membantu pengembangan organisasi Nahdlatul Ulama dan organisasi di bawahnya, misalnya Anshor. ${ }^{8}$ Kyai yang lain menandaskannya keuntungan itu pada sesuatu yang lebih umum yakni pentingnya perlindungan bagi umat Islam di Jawa Barat melalui pondok pesantren di Cirebon dari upaya-upaya politik di luar pesantren yang ingin melemahkan pesantren. Misalnya, katanlah upaya merebut pengaruh pesantren, tetapi digunakan untuk kepentingan yang tidak mendukung pada pondok pesantren ke depan, terutama ingin memperlemah ideologi ahlussunnah wal jama' $a{ }^{\prime}{ }^{9}$

Lepas dari semua pilihan politik itu, faktor terpenting bagi para Kiai dalam berpolitik adalah adanya motivasi politik yang

\footnotetext{
${ }^{7}$ Ibid. Kyai Adib menyebutkan bahwa beberapa gedung di Pondok Buntet Pesantren merupakan bentuk nyata sumbangan itu dari beberapa partai politik yang berbeda-beda.

${ }^{8}$ Wawancara dengan KH. Muhammad Fariz, Pengasuh Pondok Buntet Pesantren. Ahad, 23 September 2012.

${ }^{9}$ Wawancara dengan KH. Hasanuddin Kriyani, Pengasuh Pondok Buntet Pesantren, 10 Oktober 2012.
} 
benar, yaitu seperti yang diajarkan oleh Rasulullah, amar makruf nahi mungkar dan memakai pendekatan dengan etika dan prinsip Islam. Tujuan sosial dari politik adalah mengeimplementasikan mashlahah atau kebaikan untuk umat. Logika praktik kelembagaan politik dengan kaidah tradisional dari ajaran Islam dipahami bahwa jika Qur'an adalah sumber ajaran Islam, maka politik adalah kendaraan untuk melaksanakannya di bumi. Kendaraan ini adalah tiang penyangga bagi misi amar ma'ruf nahi mungkar, atau misi memerintah kebaikan dan melarang kemungkaran.

Pengorganisasian amar ma'ruf nahi munkar disesuaikan dengan jaman, salah satunya adalah sistem trias politika dengan kelembagaan politik legislatif, eksekutif dan judicativ. Hal ini disandarkan atas hadits mengenai tugas umas Islam dalam hal menghadapi kemungkaran. Walaupun dengan analogi yang tidak komplit dari sebuah hadits, namun telah memberikan penjelasan yang memudahkan. Yaitu, bahwa umat Islam dituntut untuk meresponnya melalui tiga alternatif, pertama menyelesaikan dengan tangan, yang dimaknai sebagai kekuasaan eksekutif yang efektif, kedua diselesaikan dengan lisan, yang dimaknai sebagai kekuasaan legislatif yaitu bersuara untuk membangun peraturan perundangan, dan ketiga dengan hati, dimaknai sebagai dukungan bagi pemerintah dari masyarakat. ${ }^{10}$

\section{Pandangan Masyarakat}

Pondok Buntet Pesantren, yang dikenal oleh banyak kalangan sebagai pesantren yang sangat terbuka dalam persoalan politik, mendapatkan pandangan beragam dari masyarakatnya. Namun, pandangan umum yang diberikan adalah "Buntet iku angel dicandake (Buntet itu susah dipegangnya)". ${ }^{11}$ Hal ini didasarkan karena Buntet Pesantren, secara kelembagaan, tidak pernah benarbenar memiliki pilihan politik yang tegas. Tetapi ia menerima semua kepentingan politik yang datang merangsek kesana. Buntet

\footnotetext{
${ }^{10}$ Wawancara dengan KH. Muhammad Fariz, Pengasuh Pondok Buntet Pesantren. Ahad, 23 September 2012.

${ }^{11}$ Wawancara dengan H. Ahmad Marzuki, Tokoh Masyarakat (pengurus MWC NU Kecamatan Astanajapura), Rabu, 7 November 2012.
} 
tidak bermain politik tetapi memainkan 'kepentingan politik' para politisi.

Pilihan sikap politik 'netral' yang ditempuh oleh Buntet Pesantren berdampak terhadap pandangan politik masyarakat, baik secara langsung maupun tidak. Secara umum, masyarakat menilai sikap tersebut sebagai sikap yang sudah semestinya diambil oleh Buntet Pesantren. "Saya tidak sepakat pesantren (Buntet, red.) terlibat politik. Pesantren itu lembaga pendidikan yang netral, orientasinya itu pengembangan pendidikan, soal kemudian secara personal Kyai atau hak untuk memilih kelompok atau partai atau kelompok tertentu itu soal lain". ${ }^{12}$ Sebagai lembaga pendidikan dan dakwah, Buntet Pesantren dan para kyainya sudah semestinya menjaga jarak dengan urusan politik, mulai dari memberikan dukungan terhadap partai politik atau calon tertentu hingga keterlibatan secara langsung dalam partai politik dan pencalonan. “...inilah sikap yang benar, inilah yang diinginkan oleh NU. Pesantren itu harus menjaga jarak yang sama dengan semua partai, semua steak holder politik". 13 "Sebenarnya pandangan saya melihat para ulama (Buntet Pesantren, red.) yang terjun langsung atau berperan aktif dalam politik menurut saya kurang baik. Karena disamping beliau itu seseorang yang memempunyai citra baik dalam agama menjadikan orang tersebut kurang untuk menjadi panutan dalam hal pendidikan agama. Sebenarnya sudah ada bagian masing-masing, seharusnya menjadi monitoring kepada pemerintah saja". ${ }^{14}$ Keterlibatan kyai dalam suatu partai politik juga menjadi persoalan. "Karena kalau beliau masuk partai politik, berarti beliau seolah-olah mengagungkan partai politik itu. Nantinya bisa menjadi pelajaran atau teladan bagi santrinya. Saya sebagai orang tua tidak mau anak saya dididik mengenal politik praktis, tapi mengenal akhlak, dan ilmu pendidikan agama dan umum". ${ }^{15}$

${ }^{12}$ Wawancara dengan Ade Duriawan, walisantri Pondok Buntet Pesantren, 34 tahun, Selasa, 20 November 2012.

${ }^{13}$ Wawancara dengan Didi Khumaedi, Tokoh Masyarakat, Senin, 26 November 2012.

${ }^{14}$ Wawancara dengan Fadli Hamdillah, allumnus Pondok Buntet Pesantren, 28 tahun. Jum'at, 16 November 2012.

${ }^{15}$ Wawancara dengan Euis Suhartati Pratawijaya, walisantri Pondok Buntet Pesantren, 50 tahun, Selasa, 20 November 2012. 
Demikian pula dalam hal memberikan dukungan. Sudah semestinya Buntet Pesantren tidak terlibat dalam aksi dukungmendukung partai politik dan calon tertentu. Karena kredibelitas pesantren dan citra kyai lah yang dipertaruhkan. Apalagi jika sang kyai mengharuskan santri-santrinya untuk mendukung pilihannnya. "Jangan sampai ditekan semua santri untuk mendukung ini, mendukung itu. Kalau hanya menyarankan dan memberikan pandangann sih gak masalah. Tapi kalau tidak memilih ini nanti akibatnya begini, itu tidak setuju. ${ }^{16}$ Kalah dan menang atau jadi dan tidak jadi calon yang didukung akan berdampak buruk bagi pesantren dan kyai. Jika menang, orang akan bertanya-tanya dibayar berapa kyai itu sehingga dapat memenangkannya. Jika kalah, kepercayaan masyarakat akan menurun drastis karena kekalahan itu menunjukkan betapa suara kyai itu sudah tidak lagi didengar dan diikuti oleh banyak orang. Masalah akan semakin runyam jika calon yang didukung sang kayi menang, tetapi kemudian setelah menjabat, ternyata ia tidak amanah dan bertanggungjawab, korupsi dan menyelewengkan kekuasaannya.

Sikap netral dan 'welcome' terhadap semua kepentingan politik yang ditunjukkan oleh Buntet Pesantren, disadari atau tidak, menumbuhkan kesadaran, kedewasaan dan kecerdasan politik masyarakat sekitar pesantren, terutama para alumni dan walisantrinya. Masyarakat sudah terbiasa dengan kedatangan 'tamu politik' dari bebagai latar belakang politik di pesantren ini, bahkan dalam satu kesempatan tertentu. Pada perhelatan akbar tahunan Haul Sesepuh dan Warga Buntet Pesantren, misalnya, sudah menjadi tradisi acara ini dihadiri oleh para pejabat dan tokoh politik dengan berbagai latar belakang politik, baik berskala lokal maupun nasional. Para walisantri, allumni dan masyarakat sekitar pesantren tidak merasa 'risih' dengan kedatangan mereka. Kehadiran mereka dianggap 'biasa' dan tidak berpretensi sebagai justifikasi dukungan pesantren terhadap kepentingan politik mereka. Masyarakat sadar bahwa tokoh yang datang apada acara tersebut tidak terkait dengan pencalonan mereka dan

\footnotetext{
${ }^{16}$ Wawancara dengan Romli, walisantri Pondok Buntet Pesantren, 42 tahun, Jum'at, 16 November 2012.
} 
kedatangannya tidak serta merta berarti restu dan dukungan pesantren kepada mereka. “.... kalau haul Buntet itu kan intinya itu silaturrohim. Artinya ketika berbicara silaturrohim, maka tidak ada ikatan siapapun yang harus atau tidak boleh datang kesitu. Jadi, sah-sah saja siapa saja yang mau datang, entah nanti di dalamnya ada maksud-maksud tertentu, wallahu a'lam". ${ }^{17}$

Kehadiran para pejabat dan tokoh politik ke Buntet Pesantren bahkan dianggap sebagai sesuatu yang sudah semestinya dan menggembirakan karena “... jangan sampai ulama yang mendekati para politisi atau pemerintah, tapi selayaknya pemerintah yang turun menemui para kiyai ${ }^{18}$. "Sebenarnya acara seperti (haul Buntet, red.) itu malah memberikan citra yang baik antara pemerintah dengan pesantren. Karena hal tersebut bisa menjadikan keharmonisan antara pemerintah dan pesantren. Kalau bisa di jadikan sebuah acara rutinitas antara pemerintah dan alim ulama untuk bisa berbaur dan bisa mengetahui politik. ${ }^{19}$ Kehadiran mereka juga dianggap sebagai prestise karena berarti pesantren telah mendapat perhatian lebih dari mereka, dan dianggap sebagai berkah dan kesempatan untuk kemajuan pesantren. " $\ldots$ saya kira haul itu menjadi bagian momen yang memang harus dimanfaatkan oleh pesantren (Buntet, red) sebagai momen penting untuk menghadirkan tokoh-tokoh nasional. Kedatangan para tokoh itu saya kira dimanfaatkan untuk kontribusi perkembangan di Buntet, soal dari mana partainya dari tokoh mana dan sebagainya bagi saya saya itu tidak masalah, yang penting orientasi mereka ketika mereka hadir di Buntet adalah bagai mana mereka bisa memberikan kontribusi yang positif dan riil terhadap perkembangan pesantren di Buntet" 20 .

Satu hal penting yang menjadi catatan tentang kehadiran para pejabat dan tokoh politik di pesantren termasuk Buntet

${ }^{17}$ Wawancara dengan Miftahul Khoir, allumnus Pondok Buntet Pesantren, 28 tahun, Selasa, 22 November 2012.

${ }^{18}$ Wawancara dengan Abdul Mukti Jaya Karta, allumnus Pondok Buntet Pesantren, 29 tahun, Selasa, 22 November 2012.

${ }^{19}$ Wawancara dengan Fadli Hamdillah, allumnus Pondok Buntet Pesantren, 28 tahun. Jum'at, 16 November 2012.

${ }^{20}$ Wawancara dengan Ade Duriawan, walisantri Pondok Buntet Pesantren, 34 tahun, Selasa, 20 November 2012. 
Pesantren adalah pelepasan 'kepentingan politik' tokoh-tokoh tersebut, entah itu kampanye, penggalangan dukungan dan sebagainya. “....ya tidak apa-apa. Toh beliau juga datang kesini (Buntet Pesantren, red.) cuma silaturahmi. Selagi dia tidak menekan. Kunjungannya itu tidak dalam kampanye, artinya sambutan-sambutan, dukung-mendukung dan lain-lain. Kalau Dia hadir, datang, terus mengikuti acara sialturahmi ke pesantren, apalagi membantu pesantren, ya setuju-setuju aja”. 21 “...kalau acara resmi tahunan pesantren (haul Buntet, red.) digunakan kampanye, sangat tidak setuju, mengambil kesempatan dalam kesempitan. Sebenarnya warga dan santri pun bisa menilai, apakah ini kampanye atau tidak. Sebaiknya diperbanyak tausiyah-tausiyah saja". 22

\section{Ijtihad Politik Buntet Pesantren; Pragmatis-oportunis atau Apatisme Politik?}

Siapa memainkan siapa dan siapa memanfaatkan siapa, menjadi tema utama ketika membincang fenomena keterlibatan pesantren dan kyai dalam aktifitas politik. Hal ini tentu saja karena dalam dunia politik tidak ada sesuatu yang abadi kecuali 'kepentingan politik' itu sendiri. Hari ini kawan besok lawan dan hari ini dimanfaatkan besok memanfaatkan karena fluktuasi kepentingan politik adalah hal yang lumrah. Ketika pesantren dan kyai 'bermain' politik, entah itu secara langsung dengan menjadi calon atau pengurus partai maupun hanya dengan aksi dukungmendukung, maka pertanyaan diatas akan segera mengemuka. Apakah para politisi memainkan dan memanfaatkan pesantren untuk kepentingan politik mereka ataukah justeru pesantren bisa memainkan dan memanfaatkan kepentingan politik para politisi. Apakah pesantren diseret-seret mengikuti hasrat politik dalam pendulangan suara ataukah pesantren dapat memainkan dan memanfaatkan situasi politik demi kepentingan dan kemaslahatan pesantren.

${ }^{21}$ Wawancara dengan Romli, walisantri Pondok Buntet Pesantren, 42 tahun, Jum'at, 16 November 2012.

${ }^{22}$ Wawancara dengan Fadli Hamdillah, allumnus Pondok Buntet Pesantren, 28 tahun. Jum'at, 16 November 2012. 
Dalam konteks wacana diatas, pengalaman panjang Buntet Pesantren dalam 'bermain' politik memungkinkannya menjadi lebih matang dan lincah dalam menyikapi situasi politik paling mutakhir, era multipartai. Buntet Pesantren memilih sikap 'netral' dan 'welcome' terhadap partai politik manapun. Sikap ini diambil karena dalam pandangan Buntet Pesantren partai politik yang ada itu sama saja, terjebak pada kepentingan sekterian dan kelompoknya masing-masing. Maka dari itu, daripada pesantren dimanfaatkan oleh kepentingan sekterian partai politik itu lebih baik pesantren balik memanfaatkan mereka. Makanya, tidak masalah bagi Buntet Pesantren hari ini mendukung Golkar, besok mendukung Demokrat atau yang lainnya.

Ijtihad dan pilihan sikap politik Buntet Pesantren tersebut merupakan pilihan yang paling logis dan rasional di tengah kondisi carut marutnya perpolitikan nasional. Pilihan sikap ini sangat strategis dan cerdas agar pesantren tidak dimainkan dan dimanfaatkan oleh kepentingan politik bahkan justeru bisa memainkan dan memanfaatkan kepentingan politik demi kepantingan dan kemaslahatan pesantren. Hanya saja, kesan yang segera muncul dari sikap ini adalah pandangan dan sikap pragmatis dan oportunis. Politik dimaknai hanya sebagai upaya atau jalan untuk mendapatkan kepentingan sesaat dan bersifat transaksional. ${ }^{23}$ Politik 'hanya' persoalan manfaat-memanfaatkan dan main-memainkan. Siapa yang pandai memainkan dan memanfaatkan siapa.

Lalu, pertanyaannya, benarkah politik dimaknai hanya sebatas itu? Pesantren sebagai lembaga pendidikan dan dakwah serta kyai sebagai pemimpin agama, dimana tanggungjawabnya untuk memperbaiki keadaan dan transformasi sosial melalui politik? ${ }^{24}$ Bukankah dengan berpandangan bahwa partai politik sama saja, makanya, daripada partai politik memanfaatkan pesantren, lebih baik pesantrenlah yang memanfatkan mereka, berarti sudah tidak ada kepercayaan dan apatis terhadap partai politik?. "Ini yang disebut apatisme politik, dan sebenarnya sikap

\footnotetext{
${ }^{23}$ Wawancara dengan Didi Khumaedi, Tokoh Masyarakat, Senin, 26 November 2012.

${ }^{24}$ Ibid.
} 
ini menghindari politik, apolitis". ${ }^{25}$ Berpolitik dengan menghindar dari keterlibatan politik. Sikap yang menganggap bahwa partai politik dan para politisi sudah tidak bisa diharapkan lagi untuk memperbaiki keadaan, makanya lebih baik dimanfaatkan saja. Bukankah ini sikap praktis-pragmatis-oportunis dalam berpolitik yang didasari oleh apatisme politik?.

Jika diamati secara seksama, gejala apatisme politik ini memang bukan khas Buntet Pesantren, tetapi menggejala hampir di semua tempat dan menjadi fenomena khas politik kontemporer di Indonesia, hanya bentuk dan skalanya saja yang berbeda-beda. Secara umum, gejala ini dilandasi oleh pandangan sebagian besar masyarakat terhadap kondisi perpolitikan sebagai berikut :

- Proses politik melalui pemilu dan pilkada langsung belum mampu menghasilkan perubahan berarti bagi peningkatan kesejahteraan masyarakat dan kejenuhan proses politik itu yang dipandang sebagai kegiatan seremonial berdemokrasi yang lebih menguntungkan bagi para elit politik.

- Merosotnya integritas moral aktor-aktor politik (elit politik) yang berperilaku koruptif dan lebih mengejar kekuasaan/kedudukan daripada memperjuangkan aspirasi publik.

- Tidak terealisasikannya janji-janji yang dikampanyekan oleh elit politik kepada publik yang mendukungnnya

- Menurunnya kinerja partai politik yang tidak memiliki platform politik yang realistis dan kader politik yang berkualitas serta komitmen politik yang berpihak kepada kepentingan publik, melainkan lebih mengutamakan kepentingan kelompok atau golongannya.

Alhasil, penyebab utama sikap apatis terhadap politik adalah kian rendahnya kepercayaan terhadap politik yang berlangsung dan rendahnya ketertarikan terhadap proses politik. Sikap apatis menganggap kegiatan berpolitik sebagai sesuatu yang sia-sia, sehingga sama sekali tidak ada hasrat untuk beraktivitas di dunia politik. Apatisme politik biasanya dikuti dengan sinisme politik, yakni sikap politik yang dimiliki orang yang menghayati tindakan dan motif orang lain dengan perasaan curiga. Sikap ini

${ }^{25}$ Ibid. 
beranggapan bahwa politik merupakan urusan yang kotor, politisi tidak dapat dipercaya, kekuasaan dijalankan oleh orang-orang yang tidak dapat dipercaya, dan individu menjadi korban dari kelompok yang melakukan manipulasi. Segala hal carut marut politik ditanggapi 'dingin' karena memang merasa tidak perlu mempersoalkannya atau karena tidak peduli. Atau sebaliknya menganggap tiada guna mempersoalkan karena sia-sia belaka sebab bakal tidak didengar; dan kalaupun didengar, tidak akan ada tindak lanjut dan solusi konkret.

Secara normatif, sikap apatis politik disebabkan oleh beberapa hal, diantaranya : pertama, apatis yang disebabkan oleh rasa bosan, yakni rasa apatis yang terjadi karena suatu kondisi yang terus berulang tanpa ada hasil sesuai yang diingini. Kedua, apatis yang disebabkan oleh pengetahuan hal ihwal politik secara memadai. Politik dipahami secara sparatis, samar atau bahkan tidak dipahami sama sekali, sehingga yang diperoleh adalah informasi yang tidak utuh dan sebagai imbasnya muncul kecendrungan untuk tidak peduli. Ketiga, apatis yang disebabkan oleh intimidasi. Ini bisa dilihat dari dua aspek, intimidasi secara langsung dan tidak langsung. Intimidasi langsung seperti adanya ancaman yang membahayakan diri, menyakiti diri bahkan menghilangkan nyawa, termasuk ancaman materiil lainnya. Sedangkan intimidasi secara tidak langsung artinya ada upaya pencitraan negatif melalui pemberitaan dan pewacanaan, seperti: politik itu kotor, agama itu bersih, sehingga politik dan agama harus dipisahkan.

Pada tataran yang paling memperihatinkan, sikap apatis politik yang disemai dengan sikap pragmatis dan oportunis akan menyuburkan praktek politik uang dengan segala bentuk manifestasinya. Tengok saja di warung- warung kopi itu terdengar obrolan seperti ini : "Ah persetan dengan siapa yang jadi atau menang, toh nasib kami tetap sama, mending pilih yang ngasih duit”. Orang Jawa bilang 'tumbu ketemu tutup', satu sama lain saling memerlukan ketika situasinya pas. Si calon dan politisi memerlukan dukungan, warga memerlukan imbalan uang atau beras atau apa saja bentuk materi lainnya. 
Terjadilah lingkaran setan politik yang berujung pada bobroknya kualitas demokrasi. Lingkaran setan itu berlangsung begini, para politisi berusaha dengan berbagai cara baik yang samar maupun halus untuk menawarkan 'iming-iming' kepada para calon pemilih. Sebaliknya para pemilih yang termasuk kelompok apatis ini juga sudah 'pandai'. Para pemilih ini sudah tidak perduli partai apa atau siapa orangnya. Yang penting bagi mereka adalah apa dan seberapa besar yang mereka peroleh ketika 'memberikan' suaranya. Ibaratnya berapa nilai pembelian suara mereka. Bagi mereka ini, siapapun yang terpilih baik tingkat lokal maupun sekala nasional adalah sama saja. Mereka tetap melarat. Pendidikan semakin mahal. Lapangan usaha semakin sulit. Belum lagi tertimpa pemberitaan di televisi soal carut marut hukum, politik dan korupsi. Jadilah kelompok grassroot ini semakin apatis. Ujung dari keapatisan ini adalah pikiran untuk memperdagangkan 'suara' mereka ketika 'dibutuhkan'.

Sebenarnya apatisme politik memang cukup beralasan. Banyaknya pejabat politik dan elit politik yang tertangkap sebagai seorang koruptor, penyuap dan skandal kriminal lainnya membuat pendidikan Politik yang negatif. Secara normatif ini akan menggeiring penilaian tentang politik bahwa hal-hal yang berbau politik adalah hal yang hitam, penuh intrik, jahat, saling menjatuhkan satu sama lain. Saking buruknya, bahkan jika seseorang yang semula ditokohkan, dimuliakan, dihormati, akan kehilangan sebagian martabatnya saat memutuskan masuk politik. Publik menjadi kehilangan objektivitasnya dan jadi sensitif. "Loh kok Pak Anu masuk politik.? Loh kok Pak Anu masuk partai itu?. Loh kok.?". Kita sudah sampai tahap merasa wajar jika ada pemberitaan media tentang ulah anggota DPR yang kekanakkanakan, amoral, tukang tidur waktu sidang, korup dll. Sebaliknya, kita akan merasa aneh, janggal, dan heran jika ada pemberitaan bahwa ada anggota DPR yang berprestasi, moralis, pekerja keras.

Bentuk lain dari sikap apatis terhadap politik adalah munculnya kelompok yang disebut golongan putih (golput). Kelompok ini diartikan sebagai sekelompok orang yang memenuhi sarat untuk memilih tetapi tidak menjatuhkan pilihan hak suara saat pemilihan umum dengan berbagai alasan. Beberapa alasan 
yang mendasari seseorang yang menghindar dari aktivitas politik (golput) adalah: pertama, karena ketakutan akan kosekuensi negatif dari aktivitas politik. Orang beranggapan aktivitas politik merupakan ancaman bagi kehidupannya. Kedua, karena orang beranggapan bahwa berpartisipasi dalam kehidupan politik merupakan kesia-siaan. Orang merasa tak ada gunanya berpartisipasi karena tidak akan mempengaruhi proses politik. Ketiga, karena tidak adanya rangsangan untuk berpartisipasi dalam kegiatan politik. Politik bukanlah sesuatu yang penting untuk ditekuni. Politik tidaklah lebih penting daripada menyelesaikan pekerjaan atau rutinitas. (Rafael Raga Maran, 1999: 156). Dengan kata lain :

"Ada yang tidak ikut pemilihan karena sikap acuh tak acuh dan tidak tertarik oleh, atau kurang paham mengenai, masalah politik. Ada juga karena tidak yakin bahwa usaha untuk mempengaruhi kebijakan Pemerintah akan berhasil dan ada juga yang sengaja tidak memanfaatkan kesempatan memilih karena kebetulan berada dalam lingkungan dimana ketidaksertaan merupakan hal yang terpuji” McClosky (1972:20).

Muncul dan maraknya golput itu karena banyaknya penyimpangan yang dilakukan oleh Elit politik seperti aksi curang dalam pemilu, manipulasi data, kampaye hitam, dan premanisme politik sehingga menimbulkan ketidak percayaan masyarakat terhadap calon yang akan dipilih. Selain itu, persaingan politik yang kurang sehat yang dipertontonkan oleh elit politik membuat kejengahan masayarakat. Tidak adanya calon yang dapat membawa perubahan dan setidaknya memberiharapan yang kongkrit membuat konsituen enggan datang ke TPS. Karena bagi konstituen memilih atau tidak memilih sama saja karena tidak akan terjadi perubahan.

Bila mengacu pada konsep demokrasi dimana masyarakat atau konstituen menjadi aktor utama, maka sikap apatis terhadap politik tersebut menjadi problem besar. Bagaimana pun dalam usaha pembentukan sebuah pemerintahan sangat dibutuhkan masyarakat didalamnya. Bila hal ini dibiarkan maka akan menyebabkan gagalnya penyelesaian masalah politik, sehingga 
terpaksa menikmati sebuah kondisi yang tidak sesuai keinginan. Hal ini justru akan menguntungkan pihak-pihak yang memancing di air keruh. Sebagai contoh apatis terhadap pemilu karena ketidakyakinan adanya perubahan tapi tidak melakukan aktivitas perubahan apapun justru membuat pihak yang tidak layak jadi pemimpin akan memimpin. Hal itu akan mengukuhkan kepemimpinan yang merugikan.

Apatisme politik, baik di negara yang sudah mapan dengan demokrasi maupun yang masih dalam proses konsolidasi seperti Indonesia, jelas tidak menguntungkan. Dalam konteks Indonesia, apatisme politik dapat mengakibatkan kian terbengkalainya agenda-agenda konsolidasi demokrasi, seperti pemberdayaan pranata dan institusi demokrasi semacam partai politik, lembaga perwakilan rakyat (DPR); penciptaan good governance dan pemberantasan korupsi; penguatan kultur politik demokratis, civic culture (budaya kewargaan) dan civility (keadaban); serta penegakan hukum.

Nah, terkait sikap politik Buntet Peasntren, pertanyaan mendasarnya adalah apakah pilihan sikap politik yang sedang diijtihadi dan dijalankan oleh Buntet Pesantren itu sudah merupakan pilihan yang paling tepat?. Sebagai pesantren yang memiliki sejarah panjang berkiprah dalam politik dan pesantren besar yang memiliki pengaruh kuat di berbagai kalangan, rasanya tidak cukup peran politik Buntet Pesantren 'hanya' sebatas itu. "Mestinya Buntet bisa menjadi, katakanlah, sebagai rujukan etis politis partai-partai. Jadi misalkan partai A salah, Buntet bisa menegur. Bukan hanya mendukung tapi juga mendesain. Buntet lah yang mewarnai politik bukan diwarnai politik. Harus punya orang untuk mewarnai. Ada pertanggungjawaban moral, bukan hanya memainkan. Kalau demikian pertanggungjawabannya besar. Kalau jadi, bisa diarahkan, ketika tidak jadi, sudah ikhtiar.,"26

Dalam hal memberikan dukungan “...seharusnya kyailah yang mencalonkan, siapa ditunjuk, lalu didukung. Bukan kemudian

${ }^{26}$ Ibid. 
sudah ada orang yang mencalonkan, lalu minta dukungan. Itu kan bukan pilihan kyai". ${ }^{27}$

\section{Kesimpulan}

Pondok pesantren memiliki peran sebagai lembaga pendidikan keagamaan (tafaqqahu fiddien) dan sebagai lembaga pelayanan sosial kemasyarakatan (dakwah). Peran pesantren sebagai lembaga pendidikan yang megajarkan ilmu keagamaan dan nilai-nilai kesantunan tidak banyak di soroti oleh para politisi kecuali para pemerhati pendidikan, namun pesantren sebagai lembaga dakwah yang berhubungan secara langsung dengan masyarakat sangat menarik perhatian para politisi sebagai bidikan untuk mengangkat suara partai politiknya.

Sementara itu, keterlibatan kyai sebagai tokoh sentral pesantren dalam ruang politik mesti dipandang secara serius. Sebab, sebagaimana dipahami bahwa politik di Indonesia sangat sarat dengan fragmentasi kepentingan sesaat, sedangkan kyai merupakan sosok yang membawa misi ketuhanan yang berlaku dalam jangka waktu yang tak terbatas. Moralitas dan misi keagamaan sangatlah berbeda dengan moralitas dan misi politik. Moralitas dan misi agama bersandar pada citra ilahi yang mengandaikan totalitas pengabdian dan keihlasan yang terkait dengan dimensi esoterik yang bersifat metafisik sedangkan politik bercorak profan, sekuler dan terkait dengan posisi kuasa.

Pandangan masyarakat atas keterlibatan pesantren dan kyai dalam persoalan politik (baca: politik praktis) mengemuka menjadi dua arus besar pandangan dengan basis argumentatif yang mendasarinya. Bagi mereka yang menolak, mendasarkan argumentasinya bahwa politik bukanlah dunianya kyai, sebagai pemegang otoritas pesantren. Politik itu dunia yang kotor penuh dengan intrik, manipulasi, kolusi dan konflik. Dalam dunia politik, sangat sulit untuk membedakan siapa dalang dan siapa yang menjadi wayang. Karena bisa saja seseorang tampil sebagai wayang, namun dilain waktu, bisa juga muncul sebagai dalang, alias profokator. Hal

${ }^{27}$ Ibid. 
ini tentu saja bertolak belakang dengan citra kyai dan pesantren yang sakral. Sudah semestinya politik dipisahkan jauh-jauh dari pesantren

Bagi sebagian kalangan, kyai memang seharusnya tidak masuk ke kancah politik praktis, dan tetap berkonsentrasi di bidang keagamaan dan kemasyarakatan. Alasannya, wilayah kyai adalah sakral, berdimensi gerakan moral yang penuh dengan nilai-nilai keikhlasan, tanpa tendensi dan ambisi, menjadi milik semua golongan. Sedang dunia politik adalah profan yang meniscayakan adanya kepamrihan, penuh muatan politis, tendensius, dan akibatnya para kyai hanya menjadi alat politik kelompok tertentu. Jika berpolitik praktis dan menjadi juru kampanye parpol, para kyai akan terjebak pada logika politik (the logic of politics) yang sering memanipulasi umat atau masyarakat basisnya demi kepentingan politik, yang pada gilirannya menggiring ke arah logika kekuasaan (the logic of power) yang cenderung kooptatif, hegemonik, dan korup. Akibatnya, kekuatan logika (the power of logic) yang dimiliki kyai, seperti logika moralitas yang mengedepankan ketulusan pengabdian terhadap masyarakat basisnya akan menjadi hilang, terkalahkan oleh logika kekuasaan tadi.

Sementara itu, bagi yang berpendapat sebaliknya, berpandangan bahwa keterlibatan kyai dan pesantren dalam persoalan politik merupakan suatu keharusan dan kewajaran. Dalihnya, justru karena politik sedang kotor, kehadirannya diharapkan mampu menyemarakkan wacana politik baru kontemporer dan meniupkan arah baru pemikiran politik. Sebagai sosok yang selama ini dianggap penuh dengan kekuatan aura kharismatik serta menempati posisi tinggi (high class) dalam strata sosial, utamanya bagi umat islam, tidak mengherankan jika segala apa yang diucapkan seorang kyai, diyakini sami'nâ wâatho'na. Karena itu, ditengah kian merosotnya citra politik tersebut, kyai harus masuk dan ikut berpartisipasi dalam politik parktis untuk segera memperbaiki semua kebobrokan yang terjadi didalamnya. Terlebih dengan kian merosotnya citra para elite politik dimata masyarakat, hal itu bertolak dari fakta yang terjadi selama ini, perilaku para wakil rakyat kian jauh dari implemantasi amar ma'ruf nahi mungkar. Kalau seorang kyai "lepas tangan", sama halnya ia telah membiarkan kemungkaran semakin merajalela. Sedangkan membiarkan kemungkaran di depan mata, sama juga dengan merestuinya. 
Keterlibatan kyai di dunia politik adalah bagian dari fardlu kifayah. Artinya, seluruh umat Islam ikut menanggung dosa jika tak ada satu pun umatnya yang peduli dengan politik, karena politik adalah bagian dari dinamika kehidupan yang tidak bisa ditolak kehadirannya. Sama halnya, jika seluruh umat Islam terjun di dunia politik, sehingga melupakan tugas dakwah, pendidikan, ekonomi, sosial dan keagamaan, maka seluruh umat Islam ikut terbebani dosa. Fardlu kifayah adalah kewajiban keterwakilan, jika sudah ada yang mewakili maka gugurlah kewajiban itu.

Politik kyai bukan berorientasi pada kekuasaan an sich tapi politik moral. Keterlibatan kyai dalam politik bukan berarti terjun dan turut terlibat langsung dukung-mendukung capres dan cawapres. Kyai tetap boleh berpolitik, tetapi tidak diorientasikan pada kekuasaan, melainkan menanamkan nilai-nilai moral untuk pencerdasan dan penguatan umat dan masyarakat. Jadi, saat kyai berpolitik memang akan muncul permasalahan. Namun masalahnya lebih terletak pada penggunaan otoritas dan penggunaan legitimasi, bukan pada substansi keterlibatan kyai dalam politik praktis. Jadi masalahnya, apakah terjadi 'authority abuse' saat kyai berpolitik atau tidak. Selama tidak ada penyalahgunaan otoritas, maka politik kyai tidak menjadi masalah, bahkan sangat dibutuhkan.

\section{DAFTAR PUSTAKA}

Almon, Gabriel, 2004, The Civic Culture, Jakarta: Prinecton University Press.

Budiardjo, Miriam, 1988, Dasar-Dasar Ilmu Politik, Jakarta: PT Gramedia.

Budiarjo, Miriam., 1998, Partisipasi dan Partai Politik (sebuah bunga rampai,. Jakarta: Yayasan Obor Indonesia.

Dhofier, Zamakhsyari, 1985, Tradisi Pesantren; Studi tentang Pandangan Hidup Kyai, Jakarta: LP3ES.

Firmansyah, 2007, Marketing Politik : antara pemahaman dan realitas.

Jakarta: Yayasan Obor.

Huntington, Samuel dan Nelson, Joan, 1994, Partisipasi Politik di Negara Berkembang, Jakarta: Rineka Cipta.

Keith Fauls, 1990, Political Sciology : A Critical Introduction. 
Khoiruddin, 2005, Politik kiai: Polemik Keterlibatan Kiai dalam Politik Praktis, Malang: Averroes Press Publishing.

Kusnadi dan Bintan R. Saragih, 2000, Ilmu Negara, Jakarta: Gaya Media Pratama.

Maran, Raga, Rafael, 2001, Pengantar Sosiologi Politik, Jakarta: Rineka Cipta.

Mas'oed, Mochtar dan Colin MacAndrews, 1983, Perbandingan Sistem Politik, Yogyakarta: Gadjah Mada University Press.

Meclosky, Gelbert, 1994, Ciri-Ciri Partisipasi Politik, Jakarta: Pustaka Pelajar.

Muhaimin AG, 2001, Islam dalam Bingkai Budaya Lokal, Potret dari Cirebon, Jakarta: Logos.

Norman H. Hie, 2002, Partisipasi Politik, Jakarta: Gramedia.

Rafel, Raga Maran, 2001, Pengantar Sosiologi Politik, Jakarta: Rineka Cipta.

Ruslan, Ustman Abdul Muiz, 2000, Pendidikan Politik Ikhwanul Muslimin, Solo: Era Intermedia.

Rush, Michael dan Althoff, Philip, 2000, Pengantar Sosiologi Politik, Jakarta: Raja Grafindo Persada.

Surbakti, Ramlan, 1999, Memahami Ilmu Politik, Jakarta: PT. Grasindo.

Turmudi, Endang, 2004, Perselingkuhan Kiai dan Politik, Yogyakarta: LKIS. 